\title{
Device Single Use Indicator
}

National Cancer Institute

\section{Source}

National Cancer Institute. Device Single Use Indicator. NCI Thesaurus. Code C93808.

Specifies whether a device is intended to be used only one time. 